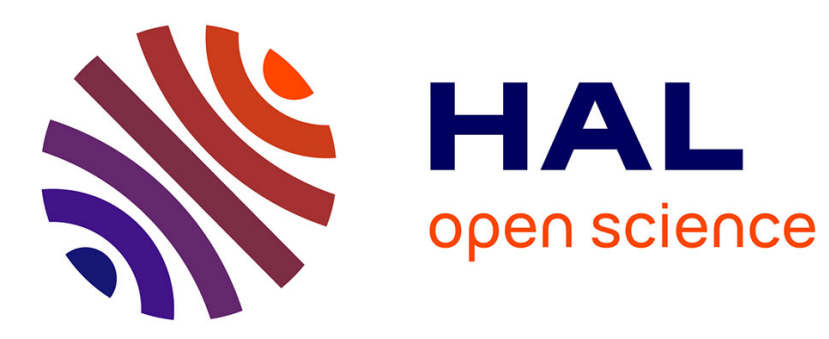

\title{
Contribution of calcium-conducting channels to the transport of zinc ions.
}

Alexandre Bouron, Johannes Oberwinkler

\section{To cite this version:}

Alexandre Bouron, Johannes Oberwinkler. Contribution of calcium-conducting channels to the transport of zinc ions.. Pflügers Archiv European Journal of Physiology, 2014, 466 (3), pp.381-7. 10.1007/s00424-013-1295-z . hal-01060686

\section{HAL Id: hal-01060686 https://hal.science/hal-01060686}

Submitted on 4 Sep 2014

HAL is a multi-disciplinary open access archive for the deposit and dissemination of scientific research documents, whether they are published or not. The documents may come from teaching and research institutions in France or abroad, or from public or private research centers.
L'archive ouverte pluridisciplinaire HAL, est destinée au dépôt et à la diffusion de documents scientifiques de niveau recherche, publiés ou non, émanant des établissements d'enseignement et de recherche français ou étrangers, des laboratoires publics ou privés. 


\title{
Contribution of calcium-conducting channels to the transport of zinc ions
}

\author{
Alexandre Bouron ${ }^{1,2,3}$, Johannes Oberwinkler ${ }^{4}$ \\ ${ }^{1}$ UMR CNRS 5249, Grenoble, France. ${ }^{2}$ CEA, DSV, IRTSV, Grenoble, France. ${ }^{3}$ Université \\ Grenoble Alpes, France. \\ ${ }^{4}$ Institut für Physiologie und Pathophysiologie, Philipps-Universität Marburg, 35037 Marburg, \\ Germany
}

Correspondence should be addressed to:

Alexandre Bouron

Laboratoire de Chimie et Biologie des Métaux

CEA

17 rue des Martyrs

38054 Grenoble, France.

Phone : 0033438784423

FAX : 0033438785487

E-mail : alexandre.bouron@cea.fr 


\begin{abstract}
Zinc $(\mathrm{Zn})$ is a vital nutrient participating in a myriad of biological processes. The mechanisms controlling its transport through the plasma membrane are far from being completely understood. Two families of eukaryotic zinc transporters are known to date: the Zip (SLC39) and ZnT (SLC30) proteins. In addition, some types of plasmalemmal calcium (Ca)conducting channels are implied in the cellular uptake of zinc. These ion channels are currently described as systems dedicated to the transport of $\mathrm{Ca}$ (and, to some extent, sodium (Na) ions). However, a growing body of evidence supports the view that some of them can also function as pathways for $\mathrm{Zn}$ transport. For instance, voltage-gated $\mathrm{Ca}$ channels and some types of glutamate-gated receptors have long been known to allow the entry of $\mathrm{Zn}$. More recently, members of the TRP superfamily, another type of Ca-conducting channels, have been shown to permit the uptake of $\mathrm{Zn}$ into eukaryotic cells. The aim of this review article is to present the current knowledge supporting the notion that Ca-conducting channels take part in the plasmalemmal transport of $\mathrm{Zn}$.
\end{abstract}




\section{Introduction}

The metal ion zinc ( $\mathrm{Zn})$ is essential to all forms of living cells. Present in extracellular fluids and intracellularly, it is, with iron $(\mathrm{Fe})$, the most abundant trace element of the human body $[18,55]$. Proteomic analysis indicated that nearly $10 \%$ of human proteins have the ability to bind $\mathrm{Zn}[4]$. At the cellular level, where its total concentration is estimated to be about 100$200 \mu \mathrm{M}, \mathrm{Zn}$ fulfils two main functions: structural and catalytic. Indeed, $\mathrm{Zn}$ is a cofactor for many enzymes and is involved in forming and maintaining the correct 3-dimensional structure of proteins such as zinc-finger proteins [39]. At rest, the cytosolic concentration of free $\mathrm{Zn}$ $\left(\left[\mathrm{Zn}^{2+}\right]\right)$ in eukaryotic cells is in the nanomolar range. It is however subject to regulation since various physiological factors like the cellular redox status or the electrical activity of excitable cells have been shown to influence $\left[\mathrm{Zn}^{2+}\right]$. These changes in $\left[\mathrm{Zn}^{2+}\right]$ seem to play essential roles in healthy and diseased states. On one hand, dietary Zn deficiency, which is associated with an increased oxidative stress Eide 2011, is a nutritional problem affecting human health ref. On other hand, Zn excess can also be harmful. This has been illustrated by in vitro studies showing that the culture medium used to maintain cell lines like PC-12, HeLa or HT-29 and primary cell cultures (cardiac cells and neurons) contains about $5 \mathrm{nM}$ free $\mathrm{Zn}$. This value is close to the baseline extracellular concentration of $\mathrm{Zn}$ found in dialysates of rat and human cerebrospinal fluids which has been reported to be $\sim 19$ nM Frederickson et al 2006. In vitro experiments showed that diminishing or increasing this free $\mathrm{Zn}$ ion concentration for instance up to $50 \mathrm{nM}$ is toxic Bozym 2010. Another example of the pathophysiological relevance of $\mathrm{Zn}$ is its role in neuronal injury caused by stroke. Accumulating evidence suggest that, together with calcium $(\mathrm{Ca})$, the intracellular accumulation of $\mathrm{Zn}$ ions participates in ischemic injury Shuttleworth \& Weiss 2011. 
In addition to its structural and catalytic properties, $\mathrm{Zn}$ is also viewed as a signaling ion exerting regulatory functions. It is now regarded as a second messenger [63] able to influence the activity of various enzymes and to control intracellular signaling pathways [52]. Its extracellular concentration is also not constant. Several types of cells have the property to release $\mathrm{Zn}$ into the extracellular space [19] like some neuronal and pancreatic cell types where $\mathrm{Zn}$ ions are present in vesicles undergoing cycles of exocytosis. In the brain the concentration of $\mathrm{Zn}$ in the synaptic cleft is not known with certainty. Depending on the method and the biological models used, values ranging from 1 to up to $100 \mu \mathrm{M}$ extracellular $\mathrm{Zn}$ have been found Paoletti et al, 2009 (but this viewed has been questioned, see for instance Nydegger et al, 2010). Extracellularly, Zn ions positively or negatively modulate the activity of a wide range of ion channels and receptors [41]. For instance, a submicromolar concentration of extracellular $\mathrm{Zn}$ is required to influence NMDA receptor activity under physiological conditions Nozaki et 2011. The fact that cells release zinc ions indicates that they need powerful mechanisms for taking up $\mathrm{Zn}$ in the first place. However, the mechanisms by which $\mathrm{Zn}$ ions enter into cells are still poorly understood. To date, two large families of eukaryotic Zn transporters have been identified: the Zip (SLC39) and ZnT (SLC30) proteins [12, 17]. Besides these actors, other $\mathrm{Zn}$ entry routes are likely to exist. Among them, Ca-conducting channels are attractive candidates. They are found in a great diversity of living organisms ranging from prokaryotes to eukaryotes. These Ca-conducting channels form a diverse group of proteins comprising multiple subfamilies with distinct molecular, biophysical, pharmacological and functional properties. They also differ in their site of expression. Although some of them are located intracellularly (e.g. in the endoplasmic reticulum), most types of Ca-conducting channels described so far are plasma membrane proteins. The aim of this article is to review the current experimental evidence showing that plasmalemmal Ca- 
conducting channels of several distinct protein families can constitute important Zn entry routes. 


\section{Voltage-gated Ca channels}

Voltage-gated Ca channels (VGCC) are highly selective Ca channels. They are however capable of permeating other types of cations such as barium (Ba) and strontium $(\mathrm{Sr})[27,46$, 54]. Although $\mathrm{Zn}$ ions exert inhibitory actions on VGCC [41], they can nevertheless permeate through them. One of the first indication that Ca-conducting channels can transport $\mathrm{Zn}$ ions came from electrophysiological recordings carried out on muscle fibres of beetle larvae and showing the existence of $\mathrm{Zn}$-dependent action potentials [22]. But in this study it was not completely clear whether $\mathrm{Zn}$ was permeating through $\mathrm{Na}$ or $\mathrm{Ca}$ channels. A subsequent work using mature molluscan neurons from subesophageal ganglions of snails showed that channels sensitive to lanthanum (La), cobalt (Co) (non specific blockers of Ca-conducting channels) and verapamil (a blocker of L-type VGCC), mediate Zn-dependent action potentials [31]. Single channel analysis of Ca currents on mouse muscle cells also indicated that VGCC could be permeable to $\mathrm{Zn}$ [62]. After these pioneering studies on muscle cells, most of the data available so far on the contribution of VGCC to the transport of $\mathrm{Zn}$ come from experiments carried out on brain cells and particularly on cultured cortical neurons. Indirect arguments in favor of VGCC as Zn entry channels were provided by studies investigating the neurotoxic properties of extracellular $\mathrm{Zn}$. For instance, a transient bath application of $\mathrm{Zn}$ with $\mathrm{KCl}$ (or AMPA) to cultured cortical neurons caused a clear cell loss that was partially prevented by Co and by blockers of L-type VGCC (diltiazem, verapamil, nimodipine) [61]. The co-application of $\mathrm{KCl}$ (or $\mathrm{AMPA}$ ) and $\mathrm{Zn}$ resulted in a strong elevation of the fluorescence of TSQ, a probe mainly interacting with membrane-bound Zn. This TSQ signal was attenuated by diltiazem. It was subsequently shown that the activation of VGCC that occurs downstream to the depolarisation caused by the activation of AMPA channels (see below) can mediate the entry of $\mathrm{Zn}$ [20]. This influx, sensitive to blockers of L-type Ca channels, was described as a crucial 
event leading to the death of rat cortical neurons in culture. This report therefore reinforced the idea that $\mathrm{Zn}$ ions can permeate $\mathrm{Ca}$ channels. A direct demonstration of the contribution of VGCC in the uptake of Zn came from whole-cell patch clamp experiments conducted on bovine chromaffin cells showing that step depolarizing pulses elicit $\mathrm{Zn}$ inward currents [56]. Chromaffin cells were loaded with Fura-2 and excited at $360 \mathrm{~nm}$. At this wavelength, Fura-2 signals are insensitive to $\mathrm{Ca}$ ions. Under these conditions, it was possible to detect a clear $\mathrm{Zn}$ entry occurring at rest. This $\mathrm{Zn}$ pathway was blocked by $3 \mathrm{mM}$ nickel (Ni) [56]. Depolarizing the membrane potential of these cells by means of a $\mathrm{KCl}$ challenge strongly augmented the entry of Zn, further indicating that VGCC may serve as a Zn entry route [56]. Live-cell imaging experiments conducted with the fluorescent probes TSQ [64] and mag-Fura-5 [49] further illustrated the role of neuronal VGCC. In cultured cortical neurons, a KCl-induced depolarization stimulated the entry of $\mathrm{Zn}$ that was strongly blocked by Gd, verapamil, and nimodipine and also, but to a smaller degree, by $\omega$-conotoxin GVIA (which inhibits N-type Ca channels) [49]. This entry of Zn through VGCC caused the degeneration of cultured neurons [64]. A more direct demonstration of the ability of neuronal VGCC to transport Zn was obtained by means of electrophysiological experiments performed on cultured murine cortical neurons [32]. In this work, it was shown that $\mathrm{Zn}$ ions entered into neuronal cells even in the presence of extracellular $\mathrm{Ca}$. Zn produced a non inactivating inward current through high-threshold VGCC. This current was sensitive to gadolinium (Gd) and nimodipine but weakly blocked by $\omega$-conotoxin GVIA. Under depolarizing conditions, Zn enters neuronal cells mainly via L-type Ca channels but also via $\omega$-conotoxin GVIA-sensitive N-type Ca channels. The involvement of VGCC in the uptake of Zn into neuronal cells has now been well documented by various methodological approaches using electrophysiological recordings, specific Zn probes like FluoZin-3 [13] or the use of ${ }^{65} \mathrm{Zn}$ [51]. This neuronal Zn uptake has been observed in cell cultures and brain slices [13]. 
In addition to the brain, organs like the heart and the pancreas have Zn-permeant VGCC. In pancreatic beta-cells kept in low glucose (basal condition), Zn entry occurred through a nonL-type Ca channel pathway which was hypothesized to be mediated by plasma membrane $\mathrm{Zn}$ transporters. Possibly, however, other ion channels, like TRP channels (see below) may also contribute to the basal $\mathrm{Zn}$ entry in pancreatic beta-cells. However, under stimulatory conditions (high glucose), L-type VGCC mediated the entry of Zn [25]. Pancreatic beta-cells thus seem to possess more than one type of $\mathrm{Zn}$ uptake system and, depending on their metabolic status, cells switch from one type to another [25]. Several Zn routes have been identified in pancreatic alpha-cells. Based on their FluoZin-3 experiments Gyulkhandanyan et al. concluded that $\mathrm{Zn}$ is, in part, transported via VGCC insensitive to dihydropyridines (inhibitors of L-type Ca channels) [26]. Gd, a non specific but potent blocker of Ca channels, and nitrendipine (a L-type VGCC blocker) were tested. Although applied at a high concentration $(50 \mu \mathrm{M})$, these agents weakly reduced the $\mathrm{Zn}$ uptake under basal and high glucose conditions. This indicates that in pancreatic alpha cells, VGCC only poorly contributed to the uptake of $\mathrm{Zn}$. So far, the identity of the plasma membrane channels responsible for $\mathrm{Zn}$ entry remains unclear.

In the heart, Fura-2 recordings and whole-cell patch-clamp experiments showed that $\mathrm{Zn}$ ions can enter into rat cardiac myocytes (and GH3 cells) via dihydropyridine-sensitive (L-type) VGCC. Furthermore, this influx of Zn can control the expression of a set of genes [5], suggesting that they can function as a second messenger. L-type VGCC from rat cardiomyocytes transport $\mathrm{Zn}$ ions and generate $\mathrm{Zn}$ currents. These dihydropyridine-sensitive channels have a higher affinity for $\mathrm{Zn}(\mathrm{Kd} \sim 0.043 \mathrm{mM})$ than for $\mathrm{Ca}(\mathrm{Kd} \sim 4.8 \mathrm{mM})$ [3].

\section{Glutamate receptors}

Studies addressing the question of the neurotoxic properties of $\mathrm{Zn}$ identified ionotropic 
glutamatergic receptors as likely Zn entry gates. As already noted [11], cultures of cortical neurons were the major biological model used to understand the contribution of these receptors.

Several routes are implied in the uptake of $\mathrm{Zn}$ under resting (non-depolarizing) conditions. Fura-2 and TSQ recordings showed that in the absence of glutamatergic (or $\mathrm{KCl}$ ) stimulation Zn uptake seemed to occur in part via channels sensitive to MK-801 or APV (two NMDA channel blockers) and insensitive to CNQX (an AMPA channel blocker) as well as to nifedipine (a L-type Ca channels blocker) $[9,34,40]$. The contribution of NMDA receptors to the import of $\mathrm{Zn}$ may seem paradoxical since $\mathrm{Zn}$ ions have long been regarded as potent blockers of NMDA receptors [40, 49]. Nevertheless, Zn seems to permeate through them when it is co-applied with NMDA, a maneuver reported to induce a strong intracellular Zn rise sensitive to antagonists of NMDA receptors $[30,45]$. The non-NMDA $\mathrm{Zn}$ pathway observed at rest was shown to be affected by blockers of the $\mathrm{Na} / \mathrm{Ca}$ exchanger like benzamilamiloride, D-methyl-benzamil-amiloride [49], and KB-R7943 [9]. This indicates that the nonNMDA-dependent $\mathrm{Zn}$ entry seen at rest involves a route where the influx of $\mathrm{Zn}$ is coupled to an efflux of $\mathrm{Na}[9,49]$ (but the contribution of this exchanger in the entry of $\mathrm{Zn}$ is controversial [40]). In addition to these pathways (channels and the $\mathrm{Na} / \mathrm{Ca}$ exchanger), some transporters seem to be also implicated in the entry of $\mathrm{Zn}$ into neurons at rest [11]. But discussing the roles of these proteins is beyond the scope of the present review.

When $\mathrm{Zn}$ is co-applied with AMPA (or kainate) it caused a marked and time-dependent elevation of the TSQ fluorescence, indicating an elevation of $\left[\mathrm{Zn}^{2+}\right][61]$. This $\mathrm{Zn}$ signal recorded under depolarized conditions had two sources: an uptake of $\mathrm{Zn}$ via Ca-conducting AMPA/kainate channels and a second pathway involving VGCC (activated by the depolarisation that develops after the opening of the AMPA channels) [49,64]. The recording 
of $\mathrm{Zn}$ currents in cultured hippocampal neurons confirmed that $\mathrm{Ca}$-conducting AMPA/kainate channels have the ability to transport $\mathrm{Zn}$. They have however a greater permeability for $\mathrm{Ca}$ than for $\mathrm{Zn}\left(\mathrm{P}_{\mathrm{Ca}} / \mathrm{P}_{\mathrm{Zn}} \sim 1.8\right)$ [30]. Furthermore, data collected from fluorescence imaging experiments suggest that extracellular $\mathrm{Ca}$ ions do not seem to interfere with the permeation of Zn through these channels [30]. Ca-conducting AMPA channels lacking the GluR2 subunit are now regarded as an important $\mathrm{Zn}$ entry pathway in the brain [50]. By showing that prion proteins $\left(\mathrm{PrP}^{\mathrm{C}}\right)$ control the uptake of $\mathrm{Zn}$ via an AMPA-dependent process, Watt et al [60] highlighted the contribution of these glutamatergic receptors in the transport of the metal. Indeed, they found that $\operatorname{PrP}^{\mathrm{C}}$ interacts through its $\mathrm{N}$-terminal polybasic region with the AMPA receptor subunits GluA1 and GluA2. Furthermore, it increases the surface expression of the GluA1 subunit. AMPA receptors are mediating the $\operatorname{PrP}^{\mathrm{C}}$-dependent $\mathrm{Zn}$ uptake observed in neuronal cells [60].

\section{Acetylcholine receptors}

Measurements of reversal potentials indicated that ionotropic cholinergic channels present at the endplate of frog muscles are permeable to $\mathrm{Zn}$ ions [2]. This was confirmed by Ragozzino et al [47] who studied the properties of the mouse muscle nicotinic acetylcholine receptors containing either $\gamma$ or $\varepsilon$ subunits expressed in the human cell line BOSC 23. Although Zn potently inhibited currents through channels containing either (gamma or epsilon) subunit, fluorescence measurements achieved with the Zn probe Newport Green indicated that $\mathrm{Zn}$ permeates through these channels. Of note, $\mathrm{Ca}$ and $\mathrm{Mg}$ did not alter the $\mathrm{Zn}$ uptake through these nicotinic acetylcholine receptors. However, the fractional $\mathrm{Zn}$ current was higher in channels containing the $\varepsilon$-subunit when compared to channels containing the $\gamma$-subunit [47]. 


\section{Transient receptor potential (TRP) channels}

The superfamily of mammalian TRP channels comprises 28 members which are organized into six subfamilies named TRPA, TRPC, TRPM, TRPML, TRPP and TRPV [57]. They form tetrameric structures participating in the transport of Ca with the exception of TRPM4 and TRPM5 which are the only monovalent selective cation channels of the TRP superfamily [28, 37]. Widely expressed, functional TRP channels are predominantly found at the plasma membrane but also, in some instances, on intracellular membranes [15]. The transport of $\mathrm{Zn}$ through TRP channels has been documented in 5 TRP subfamilies and involves the following TRP members: TRPA1, TRPC6, TRPM3, TRPM6, TRPM7, TRPML1, and TRPV6. TRPM7 was the first TRP identified as a Zn-conducting TRP channel [42]. Electrophysiological recordings revealed that it is highly permeable to $\mathrm{Zn}$ even in the presence of physiological concentrations of $\mathrm{Ca}$ and $\mathrm{Mg}$, indicating that TRPM7 could constitute a physiological pathway for Zn [42]. TRPM6, another TRP channel sharing nearly $50 \%$ of sequence homology with TRPM7, was also shown to be Zn-permeant [1]. Of note, heteromultimeric TRPM6/TRPM7 channels have also a high Zn permeability [38]. In addition to TRPM6 and TRPM7, TRPM3 is another Zn-conducting TRPM channels. The trpm3 gene encodes for a large number of different protein isoforms, due to a high degree of alternative splicing and alternative exon usage [21, 44]. Importantly, one site of alternative splicing directly and dramatically affects the pore properties of TRPM3 channels. For instance, the splice variant TRPM3 $\alpha 2$, which is endogenously expressed in pancreatic beta cells, is permeable to $\mathrm{Zn}$ ions, even in the presence of physiological concentrations of $\mathrm{Ca}$ and $\mathrm{Mg}[58$, 59]. Since beta cells co-release substantial amounts of $\mathrm{Zn}$ together with insulin [7, 48], the influx of Zn through TRPM3 channels might be physiologically relevant, although abundant 
alternative $\mathrm{Zn}$ influx pathways exist in these cells [25]. Interestingly, TRPM1 is a channel having a pore region that has an intermediate length when compared to the two pore variants of TRPM3, by having an insert of seven amino acids (LYAMEIN motif [36]). TRPM1 proteins expressed in a heterologous over-expression system (HEK293 cells) form channels that are Ca- but not Zn-permeable [36]. Instead, TRPM1 channels are inhibited by this metal. This characteristic feature of TRPM1 proteins appears to be dominant because heteromultimeric channels containing TRPM3 and TRPM1 also do not conduct $\mathrm{Zn}$ ions. The data on TRPM1 therefore show that not all Ca-permeable TRP channels are $\mathrm{Zn}$ permeable. They rather indicate that permeability to $\mathrm{Zn}$ (and possibly other trace metal ions) can be tuned selectively and independently from permeability to Ca. In the genome of Drosophila melanogaster, only a single TRPM gene (dTRPM) is present encoding for a protein that is strongly homologous to mammalian TRPM1, 3, 6 and 7 channels. Since the pore region of this protein seems to be rather short, it is, therefore, not surprising that the resulting proteins form $\mathrm{Zn}$ permeant channels [23]. Loss-of-function mutations in dTRPM diminished cellular Zn content, reduced cell size and led to larval lethality [23]. The cellular size phenotype could be partially rescued by growing the larvae on a medium with high $\mathrm{Zn}$ content, but interestingly not with larval food containing high levels of $\mathrm{Mg}$. These data indicate that dTRPM is involved in the cellular $\mathrm{Zn}$ homeostasis of fly larvae [23].

The subfamily of TRPML channels (named mucolipins) gathers 3 isoforms: TRPML1, TRPML2, and TRPML3 (or MCOLN3) [10, 57]. Mutations in the human Trpml1 gene results in a lysosomal storage disorder, mucolipidosis type IV (MLIV) [6, 53]. TRPML channels can function as a lysosomal metal transport system [33] notably TRPML1 which is Zn permeant [14]. The involvement of TRPML1 channels in Zn homeostasis has been underlined in a 
recent study showing for instance that TRPML1-/- mice and fibroblasts from MLIV patients have higher levels of chelatable Zn, notably in lysosomes and vacuolar structures [16].

The subfamily of TRPA channels comprises only one member, TRPA1. It is expressed by a subgroup of dorsal root ganglia and trigeminal neurons that respond to noxious stimuli [10, 45, 57]. Extracellular $\mathrm{Zn}$ ions were potent agonists of TRPA1 channels triggering their opening with an $\mathrm{EC}_{50}$ of $\sim 2 \mu \mathrm{M}$ whereas, when present intracellularly, they activated TRPA1 channels with an $\mathrm{EC}_{50}$ of $\sim 50 \mathrm{nM}$ [29]. TRPA1 channels heterogeneously expressed in HEK cells as well as native channels from dorsal root ganglia neurons were able to mediate an influx of $\mathrm{Zn}$ ions. Mutating a single amino acid (D915A) in the selectivity filter prevented $\mathrm{Zn}$ entry through TRPA1 [29]. The authors propose that $\mathrm{Zn}$ must gain access to intracellular sites in order to activate the channels.

TRPV6 is a member of the vanilloid family of TRP channels. The over-expression of human TRPV6 channels in HEK cells can give rise to an influx of $\mathrm{Zn}$ ions [35]. However, this latter effect was observed in the presence of $1 \mathrm{mM}$ external $\mathrm{Zn}$. Whether a TRPV6-dependent $\mathrm{Zn}$ entry could be observed at more physiological extracellular concentrations of $\mathrm{Zn}$ has to be shown.

The only member of the TRPC subfamily known to date to mediate $\mathrm{Zn}$ currents is TRPC6 [24]. This TRPC isoform was previously described as involved in the uptake of Fe in HEK and PC12 cells [43]. It was however later observed that its over-expression in HEK cells caused a clear augmentation of their total $\mathrm{Zn}$ content as well as an enhancement of the size of their mobilisable or labile pool of $\mathrm{Zn}$ (without causing any alteration in their iron content). The application of molecules known to activate TRPC6 channels such as SAG and hyperforin 
gave rise to an uptake of $\mathrm{Zn}$ which was sensitive to the extracellular concentration of $\mathrm{Ca}$. This TRPC6-dependent Zn entry up-regulated the size of the intracellular non mitochondrial pool of mobilisable $\mathrm{Zn}$ in cultured cortical neurons. None of the effects described above were seen in HEK cells over-expressing TRPC3 channels [24]. Besides TRPC3 and TRPC6 no other TRPC have been tested. Considering all the available literature, it can be seen that $\mathrm{Zn}$ permeation has only been studied in a few members of the TRP family. Evidently, it would be desirable to have data on the divalent permeation profile of all TRP channels, including the functionally identified heteromultimeric channels that can be formed by various TRP proteins.

\section{Conclusions}

As illustrated above, $\mathrm{Zn}$ can permeate through $\mathrm{Ca}$-conducting channels belonging to various families: glutamatergic receptors of AMPA/kainate and NMDA types, nicotinic acetylcholine receptors , L- and N/R-type VGCCs and TRP channels. The only TRP subfamily for which no data are available is the TRPP subfamily. TRPP2 (or polycystin-2) has been shown to transport the monovalent metal $\mathrm{Li}$ [8] but, clearly, data are missing regarding the biologically relevant metal Zn and this TRP channel subfamily. Also for most of the other families of Capermeable channels the characterization of divalent permeability is far from complete. As many isoforms exist and multimeric channels typically diversify further by forming heteromultimeric channels, completing the picture of $\mathrm{Zn}$ permeation of Ca-permeable channels is a daunting task. Nevertheless, given the importance of intracellular $\mathrm{Zn}$ as a second messenger and as a cofactor for many protein functions, the pursuit of this endeavor appears to be highly worthwhile. 


\section{Acknowledgements}

We would like to thank J. Gibon for his helpful comments and suggestions. 


\section{References}

1.

2. Adams, D.J., Dwyer, T.M. and Hille, B. The permeability of endplate channels to monovalent and divalent metal cations. J Gen Physiol, 75 (5). 493-510.

3. Alvarez-Collazo, J., Diaz-Garcia, C.M., Lopez-Medina, A.I., Vassort, G. and Alvarez, J.L. Zinc modulation of basal and beta-adrenergically stimulated L-type $\mathrm{Ca}(2+)$ current in rat ventricular cardiomyocytes: consequences in cardiac diseases. Pflugers Arch, 464 (5). 459-470.

4. Andreini, C., Banci, L., Bertini, I. and Rosato, A. Counting the zinc-proteins encoded in the human genome. J Proteome Res, 5 (1). 196-201.

5. Atar, D., Backx, P.H., Appel, M.M., Gao, W.D. and Marban, E. Excitationtranscription coupling mediated by zinc influx through voltage-dependent calcium channels. J Biol Chem, 270 (6). 2473-2477.

6. Bassi, M.T., Manzoni, M., Monti, E., Pizzo, M.T., Ballabio, A. and Borsani, G. Cloning of the gene encoding a novel integral membrane protein, mucolipidin-and identification of the two major founder mutations causing mucolipidosis type IV. Am J Hum Genet, 67 (5). 1110-1120.

7. Braun, M., Ramracheya, R. and Rorsman, P. Autocrine regulation of insulin secretion. Diabetes Obes Metab, 14 Suppl 3. 143-151.

8. Cantero Mdel, R. and Cantiello, H.F. Effect of lithium on the electrical properties of polycystin-2 (TRPP2). Eur Biophys J, 40 (9). 1029-1042.

9. Cheng, C. and Reynolds, I.J. Calcium-sensitive fluorescent dyes can report increases in intracellular free zinc concentration in cultured forebrain neurons. J Neurochem, 71 (6). 2401-2410.

10. Clapham, D.E. TRP channels as cellular sensors. Nature, 426 (6966). 517-524.

11. Colvin, R.A., Davis, N., Nipper, R.W. and Carter, P.A. Zinc transport in the brain: routes of zinc influx and efflux in neurons. J Nutr, 130 (5S Suppl). 1484S-1487S.

12. Cousins, R.J., Liuzzi, J.P. and Lichten, L.A. Mammalian zinc transport, trafficking, and signals. J Biol Chem, 281 (34). 24085-24089.

13. Dietz, R.M., Weiss, J.H. and Shuttleworth, C.W. Zn2+ influx is critical for some forms of spreading depression in brain slices. J Neurosci, 28 (32). 8014-8024.

14. Dong, X.P., Cheng, X., Mills, E., Delling, M., Wang, F., Kurz, T. and Xu, H. The type IV mucolipidosis-associated protein TRPML1 is an endolysosomal iron release channel. Nature, 455 (7215). 992-996.

15. Dong, X.P., Wang, X. and Xu, H. TRP channels of intracellular membranes. $J$ Neurochem, 113 (2). 313-328.

16. Eichelsdoerfer, J.L., Evans, J.A., Slaugenhaupt, S.A. and Cuajungco, M.P. Zinc dyshomeostasis is linked with the loss of mucolipidosis IV-associated TRPML1 ion channel. J Biol Chem, 285 (45). 34304-34308.

17. Eide, D.J. Zinc transporters and the cellular trafficking of zinc. Biochim Biophys Acta, 1763 (7). 711-722.

18. Frassinetti, S., Bronzetti, G., Caltavuturo, L., Cini, M. and Croce, C.D. The role of zinc in life: a review. J Environ Pathol Toxicol Oncol, 25 (3). 597-610.

19. Frederickson, C.J., Koh, J.Y. and Bush, A.I. The neurobiology of zinc in health and disease. Nat Rev Neurosci, 6 (6). 449-462. 
20. Freund, W.D. and Reddig, S. AMPA/Zn(2+)-induced neurotoxicity in rat primary cortical cultures: involvement of L-type calcium channels. Brain Res, 654 (2). 257264.

21. Fruhwald, J., Camacho Londono, J., Dembla, S., Mannebach, S., Lis, A., Drews, A., Wissenbach, U., Oberwinkler, J. and Philipp, S.E. Alternative splicing of a protein domain indispensable for function of transient receptor potential melastatin 3 (TRPM3) ion channels. J Biol Chem, 287 (44). 36663-36672.

22. Fukuda, J. and Kawa, K. Permeation of manganese, cadmium, zinc, and beryllium through calcium channels of an insect muscle membrane. Science, 196 (4287). 309311.

23. Georgiev, P., Okkenhaug, H., Drews, A., Wright, D., Lambert, S., Flick, M., Carta, V., Martel, C., Oberwinkler, J. and Raghu, P. TRPM channels mediate zinc homeostasis and cellular growth during Drosophila larval development. Cell Metab, 12 (4). 386397.

24. Gibon, J., Tu, P., Bohic, S., Richaud, P., Arnaud, J., Zhu, M., Boulay, G. and Bouron, A. The over-expression of TRPC6 channels in HEK-293 cells favours the intracellular accumulation of zinc. Biochim Biophys Acta, 1808 (12). 2807-2818.

25. Gyulkhandanyan, A.V., Lee, S.C., Bikopoulos, G., Dai, F. and Wheeler, M.B. The $\mathrm{Zn} 2+$-transporting pathways in pancreatic beta-cells: a role for the L-type voltagegated Ca2+ channel. J Biol Chem, 281 (14). 9361-9372.

26. Gyulkhandanyan, A.V., Lu, H., Lee, S.C., Bhattacharjee, A., Wijesekara, N., Fox, J.E., MacDonald, P.E., Chimienti, F., Dai, F.F. and Wheeler, M.B. Investigation of transport mechanisms and regulation of intracellular $\mathrm{Zn} 2+$ in pancreatic alpha-cells. $J$ Biol Chem, 283 (15). 10184-10197.

27. Hagiwara, S. and Byerly, L. Calcium channel. Annu Rev Neurosci, 4. 69-125.

28. Hofmann, T., Chubanov, V., Gudermann, T. and Montell, C. TRPM5 is a voltagemodulated and $\mathrm{Ca}(2+)$-activated monovalent selective cation channel. Curr Biol, 13 (13). 1153-1158.

29. Hu, H., Bandell, M., Petrus, M.J., Zhu, M.X. and Patapoutian, A. Zinc activates damage-sensing TRPA1 ion channels. Nat Chem Biol, 5 (3). 183-190.

30. Jia, Y., Jeng, J.M., Sensi, S.L. and Weiss, J.H. Zn2+ currents are mediated by calcium-permeable AMPA/kainate channels in cultured murine hippocampal neurones. J Physiol, 543 (Pt 1). 35-48.

31. Kawa, K. Zinc-dependent action potentials in giant neurons of the snail, Euhadra quaestia. J Membr Biol, 49 (4). 325-344.

32. Kerchner, G.A., Canzoniero, L.M., Yu, S.P., Ling, C. and Choi, D.W. Zn2+ current is mediated by voltage-gated $\mathrm{Ca} 2+$ channels and enhanced by extracellular acidity in mouse cortical neurones. J Physiol, 528 Pt 1. 39-52.

33. Kiselyov, K., Colletti, G.A., Terwilliger, A., Ketchum, K., Lyons, C.W., Quinn, J. and Muallem, S. TRPML: transporters of metals in lysosomes essential for cell survival? Cell Calcium, 50 (3). 288-294.

34. Koh, J.Y. and Choi, D.W. Zinc toxicity on cultured cortical neurons: involvement of N-methyl-D-aspartate receptors. Neuroscience, 60 (4). 1049-1057.

35. Kovacs, G., Danko, T., Bergeron, M.J., Balazs, B., Suzuki, Y., Zsembery, A. and Hediger, M.A. Heavy metal cations permeate the TRPV6 epithelial cation channel. Cell Calcium, 49 (1). 43-55.

36. Lambert, S., Drews, A., Rizun, O., Wagner, T.F., Lis, A., Mannebach, S., Plant, S., Portz, M., Meissner, M., Philipp, S.E. and Oberwinkler, J. Transient receptor potential melastatin 1 (TRPM1) is an ion-conducting plasma membrane channel inhibited by zinc ions. J Biol Chem, 286 (14). 12221-12233. 
37. Launay, P., Fleig, A., Perraud, A.L., Scharenberg, A.M., Penner, R. and Kinet, J.P. TRPM4 is a Ca2+-activated nonselective cation channel mediating cell membrane depolarization. Cell, 109 (3). 397-407.

38. Li, M., Jiang, J. and Yue, L. Functional characterization of homo- and heteromeric channel kinases TRPM6 and TRPM7. J Gen Physiol, 127 (5). 525-537.

39. Maret, W. and Li, Y. Coordination dynamics of zinc in proteins. Chem Rev, 109 (10). 4682-4707.

40. Marin, P., Israel, M., Glowinski, J. and Premont, J. Routes of zinc entry in mouse cortical neurons: role in zinc-induced neurotoxicity. Eur J Neurosci, 12 (1). 8-18.

41. Mathie, A., Sutton, G.L., Clarke, C.E. and Veale, E.L. Zinc and copper: pharmacological probes and endogenous modulators of neuronal excitability. Pharmacol Ther, 111 (3). 567-583.

42. Monteilh-Zoller, M.K., Hermosura, M.C., Nadler, M.J., Scharenberg, A.M., Penner, R. and Fleig, A. TRPM7 provides an ion channel mechanism for cellular entry of trace metal ions. J Gen Physiol, 121 (1). 49-60.

43. Mwanjewe, J. and Grover, A.K. Role of transient receptor potential canonical 6 (TRPC6) in non-transferrin-bound iron uptake in neuronal phenotype PC12 cells. Biochem J, 378 (Pt 3). 975-982.

44. Oberwinkler, J., Lis, A., Giehl, K.M., Flockerzi, V. and Philipp, S.E. Alternative splicing switches the divalent cation selectivity of TRPM3 channels. J Biol Chem, 280 (23). 22540-22548.

45. Patapoutian, A., Tate, S. and Woolf, C.J. Transient receptor potential channels: targeting pain at the source. Nat Rev Drug Discov, 8 (1). 55-68.

46. Pelzer, D., Pelzer, S. and McDonald, T.F. Properties and regulation of calcium channels in muscle cells. Rev Physiol Biochem Pharmacol, 114. 107-207.

47. Ragozzino, D., Giovannelli, A., Degasperi, V., Eusebi, F. and Grassi, F. Zinc permeates mouse muscle ACh receptor channels expressed in BOSC 23 cells and affects channel function. J Physiol, 529 Pt 1. 83-91.

48. Rungby, J. Zinc, zinc transporters and diabetes. Diabetologia, 53 (8). 1549-1551.

49. Sensi, S.L., Canzoniero, L.M., Yu, S.P., Ying, H.S., Koh, J.Y., Kerchner, G.A. and Choi, D.W. Measurement of intracellular free zinc in living cortical neurons: routes of entry. J Neurosci, 17 (24). 9554-9564.

50. Sensi, S.L., Paoletti, P., Bush, A.I. and Sekler, I. Zinc in the physiology and pathology of the CNS. Nat Rev Neurosci, 10 (11). 780-791.

51. Sheline, C.T., Ying, H.S., Ling, C.S., Canzoniero, L.M. and Choi, D.W. Depolarization-induced 65zinc influx into cultured cortical neurons. Neurobiol Dis, 10 (1). 41-53.

52. Shuttleworth, C.W. and Weiss, J.H. Zinc: new clues to diverse roles in brain ischemia. Trends Pharmacol Sci, 32 (8). 480-486.

53. Sun, M., Goldin, E., Stahl, S., Falardeau, J.L., Kennedy, J.C., Acierno, J.S., Jr., Bove, C., Kaneski, C.R., Nagle, J., Bromley, M.C., Colman, M., Schiffmann, R. and Slaugenhaupt, S.A. Mucolipidosis type IV is caused by mutations in a gene encoding a novel transient receptor potential channel. Hum Mol Genet, 9 (17). 2471-2478.

54. Tsien, R.W., Hess, P., McCleskey, E.W. and Rosenberg, R.L. Calcium channels: mechanisms of selectivity, permeation, and block. Annu Rev Biophys Biophys Chem, 16. 265-290.

55. Vallee, B.L. and Falchuk, K.H. The biochemical basis of zinc physiology. Physiol Rev, 73 (1). 79-118. 
56. Vega, M.T., Villalobos, C., Garrido, B., Gandia, L., Bulbena, O., Garcia-Sancho, J., Garcia, A.G. and Artalejo, A.R. Permeation by zinc of bovine chromaffin cell calcium channels: relevance to secretion. Pflugers Arch, 429 (2). 231-239.

57. Venkatachalam, K. and Montell, C. TRP channels. Annu Rev Biochem, 76. 387-417.

58. Wagner, T.F., Drews, A., Loch, S., Mohr, F., Philipp, S.E., Lambert, S. and Oberwinkler, J. TRPM3 channels provide a regulated influx pathway for zinc in pancreatic beta cells. Pflugers Arch.

59. Wagner, T.F., Loch, S., Lambert, S., Straub, I., Mannebach, S., Mathar, I., Dufer, M., Lis, A., Flockerzi, V., Philipp, S.E. and Oberwinkler, J. Transient receptor potential M3 channels are ionotropic steroid receptors in pancreatic beta cells. Nat Cell Biol, 10 (12). 1421-1430.

60. Watt, N.T., Taylor, D.R., Kerrigan, T.L., Griffiths, H.H., Rushworth, J.V., Whitehouse, I.J. and Hooper, N.M. Prion protein facilitates uptake of zinc into neuronal cells. Nat Commun, 3. 1134.

61. Weiss, J.H., Hartley, D.M., Koh, J.Y. and Choi, D.W. AMPA receptor activation potentiates zinc neurotoxicity. Neuron, 10 (1). 43-49.

62. Winegar, B.D. and Lansman, J.B. Voltage-dependent block by zinc of single calcium channels in mouse myotubes. J Physiol, 425. 563-578.

63. Yamasaki, S., Sakata-Sogawa, K., Hasegawa, A., Suzuki, T., Kabu, K., Sato, E., Kurosaki, T., Yamashita, S., Tokunaga, M., Nishida, K. and Hirano, T. Zinc is a novel intracellular second messenger. J Cell Biol, 177 (4). 637-645.

64. Yin, H.Z. and Weiss, J.H. Zn(2+) permeates $\mathrm{Ca}(2+)$ permeable AMPA/kainate channels and triggers selective neural injury. Neuroreport, 6 (18). 2553-2556. 